\title{
The effect environmental approach (affordances) approach to the attention and memory of children with mental disorders
}

\author{
Morteza Homayounnia Firoozjah ${ }^{1}$, Mahmoud Sheikh ${ }^{2}$, Rasool Hemayattalab ${ }^{3}$, Shahnaz \\ Shahrbanian ${ }^{4}$ \\ 1-PH.d, Motor Behavior, Department Motor Behavior, University of Tehran, Tehran, Iran. Orcid: 0000-0002-5370- \\ 0460 \\ 2-Associate professor, Ph.D Motor Behavior,Department Motor Behavior, University of Tehran,Tehran, Iran \\ (Corresponding Author). ORCID: 0000-0003-4029-3568_E-mail: prosheikh@yahoo.com \\ 3-Full professor, Ph.D Motor Behavior, Department Motor Behavior, University of Tehran, Tehran, Iran. ORCID: \\ 0000-0003-0581-6781 \\ 4-Assistant professor, Corrective Exercise \& Sport Injury, Department of physical education, University of Tehran, \\ Tehran, Iran. ORCID: 0000-0003-3104-7584
}

\section{Abstract}

Received: 10/11/2018

Accepted: 06/02/2019

Introduction: For people with developmental disabilities, understanding motor development provides a good basis for intervention, treatment and improvement.

Aim: The purpose of this study was to determine the effects of environmental affordances on attention and memory of 6 to 9 year-old children with intellectual disability. This was a practical and quasi-experimental (intervention) study.

Method: Target population included all children (6-9 years old) with intellectual disability. 50 male students were conveniently recruited as the sample of the study and randomly divided into two groups: experimental and control group (25 per each group).

The subjects of the experimental group went under training and exercises for 36 sessions, (3 times per week for 3 months), and 30 to 45 minutes per session. Tolouan-Pyrene attention test and Andrew Ray memory tests were employed to assess attention skills. Single variable covariance was used to analyze the collected data.

Results: The results indicated that the environmental affordances were effective in improving motor skills such as the perception of vision and balance $(\mathrm{p}<0.01)$. Also, the results of this study showed that the providers did not have any effect on the visual acuity variables ( $p>0.05)$.

Findings: Results of the study suggested that affordances were effective in improving attention skill $(\mathrm{p}<0.01)$, also results indicated that the affordances had no impact on memory variables $(\mathrm{p}>0.05)$.

Conclusion: The findings of this study showed that it is necessary to pay attention to the environment and environmental abilities, and applying appropriate methods for improving attention in children with mental disorders.

On the other hand, memory needs more organized clinical research, so that they can be sure of the effects of providers in memory.

Keywords: Affordances, Attention, Memory, Children with intellectual disability

How to cite this article: Homayounnia Firoozjah M, Sheikh M, Hemayattalab R, Shahrbanian Sh. The effect environmental approach (affordances) approach to the attention and memory of children with mental disorders. Shenakht Journal of Psychology and Psychiatry. 2019; 6 (1): 35-48.URL :http://shenakht.muk.ac.ir/article-1-553-fa.pdf

Copyright (c) 2018 the Author (s). Published by Kurdistan University of Medical Sciences. This is an open access article distributed under the terms of the Creative Commons Attribution-Non Commercial License 4.0 (CCBY-NC), where it is permissible to download, share, remix, transform, and buildup the work provided it is properly cited. The work cannot be used commercially without permission from the journal. 


\title{
تاثير قابليت محيط (فراهم سازها) روى توجه و حافظه داشى آموزان داراى اختلالات ذهنى
}

\author{
مر تضى همايون نيا فيروزجاه'، محمود شيخ '، رسول حمايت طلب'، شهناز شهربانيان ' \\ ا.دانش آمو خته دكترى، كروه رفتار حركتى ، دانشكده تربيت بدنى،دانشكاه تهر ان، تهران، اير ان.

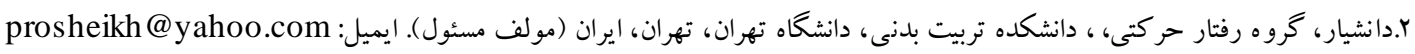

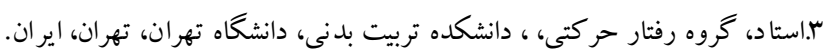

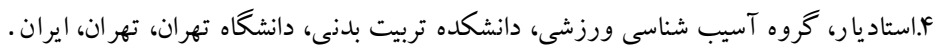

مقدمه: بر ایى افر اد با ناتو انى هاى رشدى، در كك رشد حركتى، بايهاى مناسب را بر ایى مداخله، درمان و بهبود اين افراد فراهم مى كند. هدف: هدف از يزوهش حاضر تعيين تأثير قابليت محيط (فراهم سازها) روى توجه و حافظه دانش آموزان داراى اختلالات ذهنى 9 تا ه ساله بود. اين تحقيق كاربردى و از نوع نيمه تجربى (مداخله ای) بود.

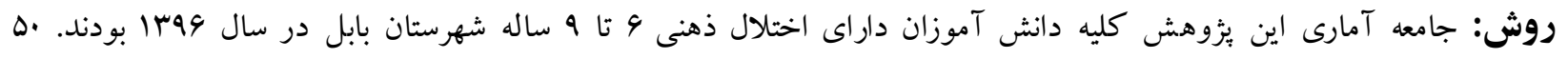

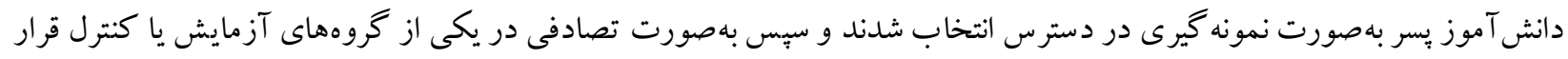

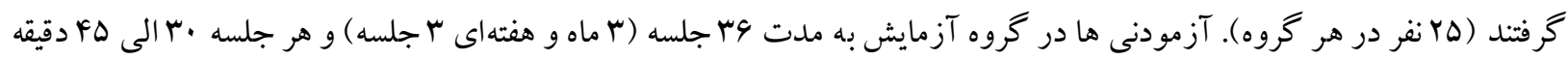

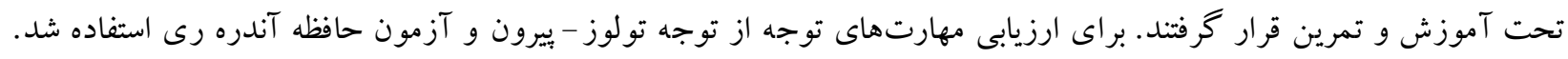

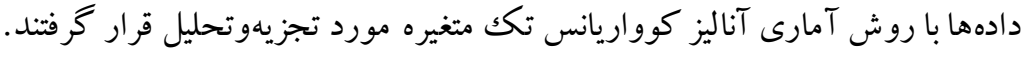
يافته ها: نتايج به دست آمده نشان داد كه فراهم سازها در بهبود مهارت توجه تأثير داشته است ( (P> P)، همجنين نتايج اين تحقيق

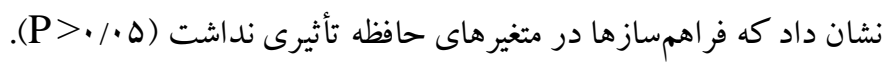
نتيجه كيرى: يافتهاى بثزوهش نشان داد كه لازم است به محيط و توانايىهاى محيطى و استفاده از روشهاى مناسب فر اهمسازى در جهت بهبود توجه در كودكان دار ایى اختلال ذهنى توجه ويزه داشت، از طرفى در مورد حافظه نيازمند تحقيقات بالينى سازمان يافته تر

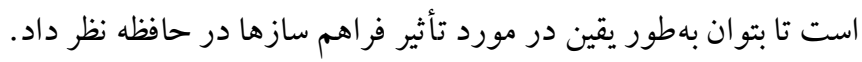
كليدوازه: فراهمسازها، توجه، حافظه، كود كان داراى اختلال ذهنى 
است كه در ساير ابعاد وجودى انسان شامل شناختى،

مقدمه

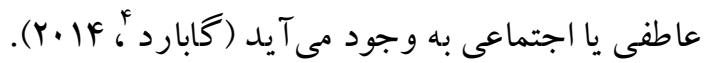
يكى از اصول مهمى كه امروزه محققان تأكيد بسيار زيادى بر اساس مشاهدات عينى و تجربى در كودكان داراى اختلال ذهنى دارد، مبحث توجه است. توجه آكاهانه به كارى كه انجام مى شود امر بسيار مهم و اساسى

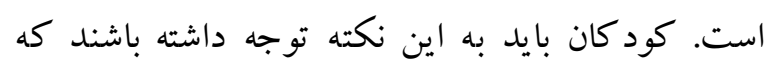
برخى از وظايف يادگيرى نسبت به وظايف ديخر به توجه بيشترى نياز دارند؛ بنابراين ميزان توجهى كه صرف يك يك وظيفه ياد گيرى مىشود به ماهيت آن وظيفه بستخى دارد دارد

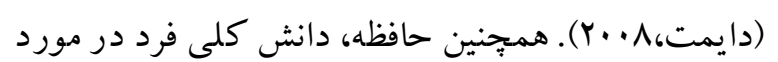

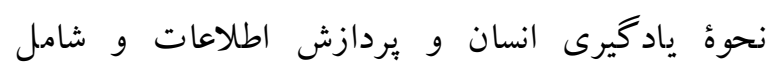
اطلاعاتى مثل تو انايى هاى حافظه، مر احل حافظه و ظرفيت آنها، نحوه بررسى مطالب و فر آيندهاى كنترل كننده

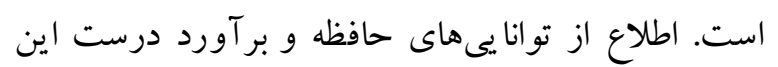
توانيى مىتو اند به فرد در اكتساب، نخهدارى و استفاده

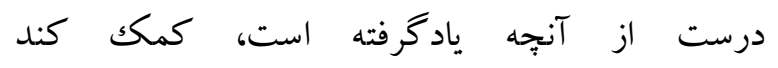

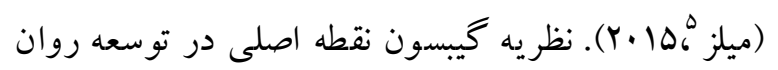
شناسى محيط بوده است و زمينه اى در توسعه و گسترش بيش از بيش در نظر داشتن فعاليت بهعنو ان روابط تعاملى

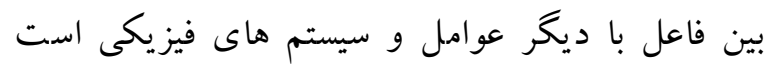

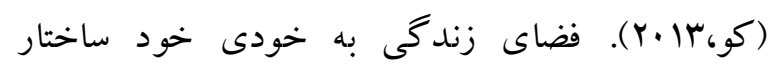
ديناميكى ندارد، بلكه بررسى هاى انگيزشى مورد نياز است تا جُخونكى تغيير و تحول اين فضا فهميده شود. كيبسون بيان داشت كه فراهم سازها نه يك ماهيت انحصاراً فيزيكى و نه روانى هستند. در نيم قرن كذشته، مطالعات قابل توجهى در زمينه نقش فراهم سازها در رشد

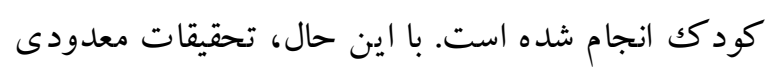

${ }_{5}^{4}$.gabbard

.milz
كودكان داراى اختلال ذهنى اغلب به مراحل اصلى نمو جسمانى دست مى يابند، اما به سبب مشكلاتى كه در رشد شناختى و روانى - حركتى دارند، در توانايىهاى ادراكى - حركتى (توجه و و حافظه) كه مستلزم يكيارجه بازى اطلاعات محيطى و تصميم گيرى براى اجراى يكك عمل ويزه است، عملكرد ضعيف دارند

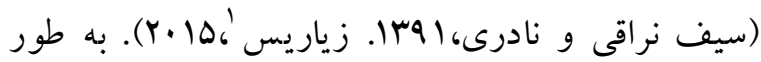
مشخص، كودكانى كه دجار ناهنجارى ها و مشكلات ذهنىاند در شروع و اجراى حركات هدف گيرى، زمان واكنشى و زمان حركت كندتر از همسالان خود عمل

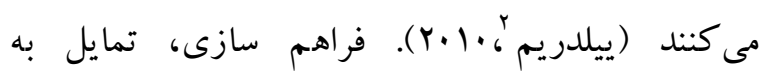
كسترش يا ترغيب تغييرات رشدى است. فراهم سازى شامل كمكك هاى حياتى، گرفتن دست و تشويق و يا

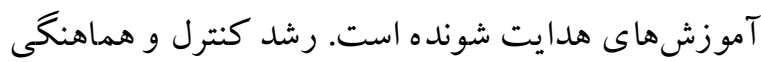
حركتى تحت تأثير عو امل مثبت (فراهمسازى) موجود در تكليف (نيازهاى اجرا، شكل گيرى الكوى حركتى و

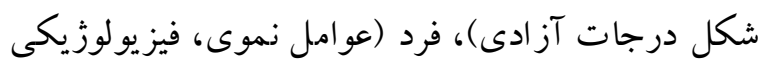
و مكانيكى و عو امل ادراكى -حركتى) و محيط (فرصت تمرين، تشويق و انگيزه، علائم آموزش و زمينه و محيط)

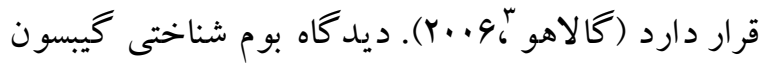
براى رشد حركتى در اوايل كودكى، تأثيرات فراهم سازهاى محيطى را بهعنوان يكك عامل مهم در رشد و

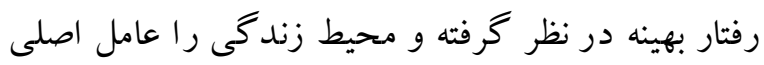
در اين زمينه قلمد اد نموده است. براى شناخت رشد بايد دانست كه شرايط تغيير رفتار حركتى ناشى از تغييراتى 
بيشتر مطالعاتى كه تا به حال در اين زمينه انجام شده از نوع على - مقايسهاى است و در اين زمينه كمتر مداخلهاى

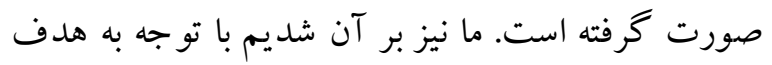
تحقيق حاضر بررسى اهميت نقش مداخله فراهمسازى محيط روى حافظه و توجه كودكان داراى اختلالات ذهنى خصوصاً در سنين بين 9 تا 9 سال بود را مطالعه نماييم؛ بنابر اين يكى از ضرورت هاى كار ما انجام مداخله در فراهم سازى محيط با تو جه به نياز موجود است تا از اين طريق بتو انيم اثر مداخلهى فراهمسازى محيط را بر تو جه و حافظه كود كان داراى اختلال ذهنى آموزش بذير مري بررسى نماييم.

\section{روش}

يزوهش حاضر كاربردى و از نوع نيمه تجربى (مداخلهاى) بو د. مطالعهاى از نوع آزمايشى با بيش آزمون

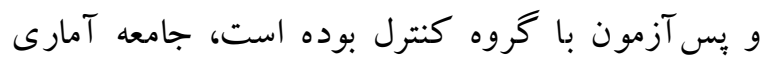
تحقيق حاضر راد انش آموزان 9 الى 9 ساله داراى اختلال ذهنى شهرستان بابل در سال تحصيلى هوس|- 9هب| تشكيل دادند كه در مجموع IVD نفر بودند. با توجه به امكانات و همكارى مديران و معلمان مدارس استثنايى شهر بابل از بين اين افراد تعداد •هد دانش آموز به صورت

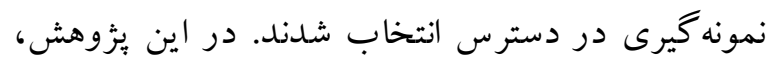
معيارهاى ورود به مطالعه شامل بهرة هوشى بين سمه تا سمل،

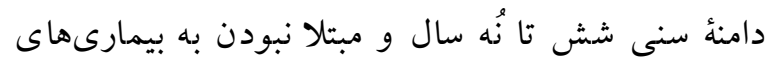
زنتيكى، قلبى، عصبى، اركانيك،، ارتويديك ) اسكلتى، عضلانى و... (ناهنجارى هاى يوسجرال و جند معلوليتى بودن و همجنين معيار خروج از مطالعهُ مشاركت منظم و

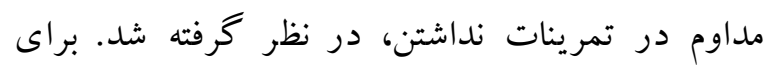
اطمينان از سلامت جسمى آزمودنىها و رعايت معيارهاى
به بررسى رابطه بين رشد حركتى و قابليت محيط در كودكان داراى اختلال هوشى در دنيا برداختهاند

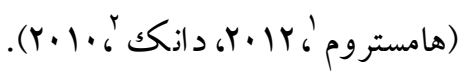

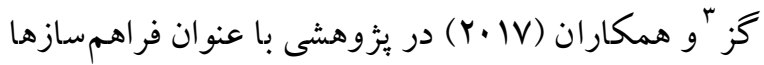
و محدوديتها در رشد حركتى و يادگيرى كودكان داراى اختلال هماهنكى رشدى نشان دادند كه نقش محدوديتها بهعنوان يكك كليد اساسى در رشد حركتى و ياد گيرى باعث درك درستى از مفهو مش رشد دارد. بايد بيان داشت كه يكى از علتهايى كه در اين تحقيق حافظه نتوانست با استفاده از فراهمسازهاى محيطى بهبود يابد مدت كم شرايط محيطى مناسب براى بهبود حافظه در

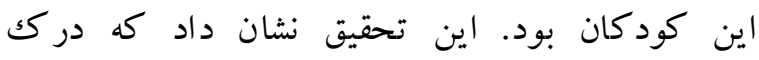
فراهمسازها و دركى تغييرات رشدى در كودكان داراى اختلالات ذهنى بسيار مهم است تا با استفاده از اين در كك بتوان نسخه مفيد براى بهبود حافظه كودكان داراى اختلال ذهنى صادر كرد. بور گن " در يزوهشى با عنوان فعاليت بدنى در فضاى روباز با استفاده از فراهم سازها بيان داشتند كه موقعيت ها و فراهم سازهايى كه در فضاى باز براى كود كان وجود دارد يكك محيط طبيعى براى ارائه كيفيت هاى بالقوه و فعاليت بدنى يك كاتاليزور

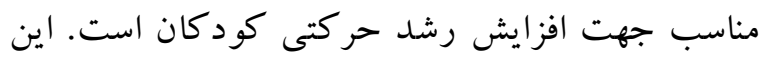
مطالعه نشان داد كه مشخصه اصلى محيطهاى باز يك عامل فرصت بخش و الهامبخش براى كودكان است

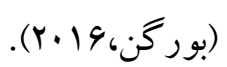

با تو جه به اينكه تحقيقات داخلى و خارجى معدودى لورى محدودى بر تأثير فراهمسازى محيط روى توجه و حافظه

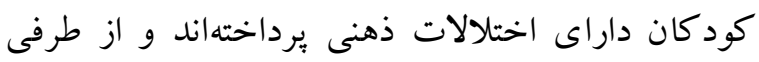

\footnotetext{
${ }^{1}$. hamestrom
2. dank
${ }^{3}$ guze
${ }^{4}$. Burgen
}

مجله روانشناسى و روان يُشكى شناخت، سال ششم، شماره ا، 
قبل شروع كار آزمون هوش استنفورد بينه با كمكك آزمونكر براى تمام شركت كنندهها تكميل و نمره هر

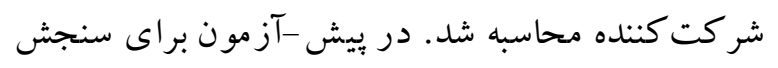
توجه از آزمون توجه تولوز- بيرون و براى سنجش حافظه از آزمون حافظه آندره رىى، طى مدت آتود دو هفته قبل از شروع طرح از هر دو گروه به عمل آمد، اين آزمونها

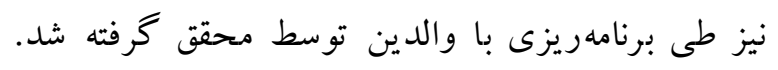
سبس گروه تجربى به مدت وب جلسه هفته (r ماه و و

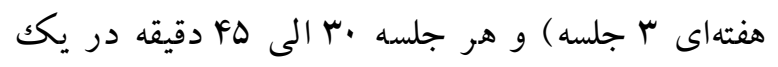

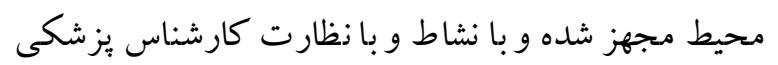
در جهت جلوگيرى از آسيبديدگى آزمودنىها قرار خواهند گرفتند و با فراهم سازهاى مهيا شده در محيط، به فعاليت مى بردازند يرداختند، در انتهاى وب جلسه دوره فراهم سازى ها با استفاده از مقياس هاى نام برده شده در بيش - آزمون رشد كود كان را مورد سنجش قرار داده شد و نمرات بيش آز مون و پِس آزمون با هم مقايسه گرديد.

\section{ابزار}

آزمون استنغورد بينه ؛ اين هوش آزماى، محتوى هوشبهر غير كلامى و كلامى است. در نسخه پپنجم

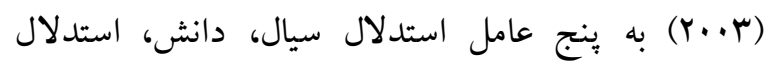
كمّى، بردازش ديدارى - فضايى و حافظهى فّّال تأكيد مى شود و هوشبهر غير كلامى و كلامى محاسبه مى گردد ئرد

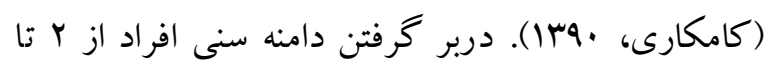
هم سال و محاسبه هوشبهر با استفاده از جداول تبديل نمرات كاملاً اختصاصى براى سنين مختلف، جزء مز اياى اين آزمون است كه سير تكاملى مقياس و مقياسهاى

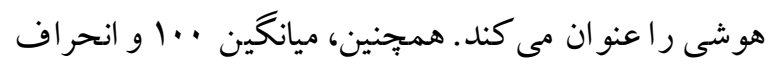

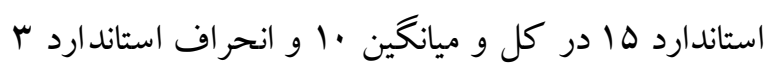

ورود و خروج مطالعه، همدٔ آزمودنىها در جلسة اول

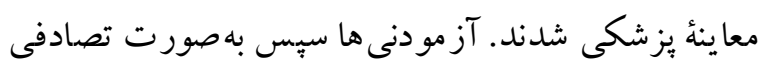
به دو گروه آزمايش و كنترل (ها نفر در هر گروه) تقسيم شدند. در اين مطالعه براى هر يكك از كروههاى آزمايش

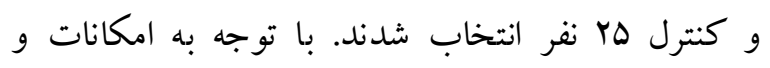
همكارى مديران و معلمان مدارس استثنايى شهر بابل

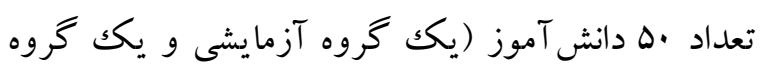
كنترل) به صورت نمونه گيرى در دسترس انتخاب شدند. براى انجام اين تحقيق ابتدا با اخذ مجوز از مراكز مورد نظر ويزه دانش آموزان استثنايى كه به تعداد مناسب دانش آموز داراى اختلالات ذهنى هو شى در آن وجود داند دارد شناسايى و انتخاب گرديد. و بر اساس نمونه ها انتخاب شد، بس از ارائه معرفىنامه دانشگاه، اهداف تحقيق شرح داده شد. سيس با اخذ مجوز از مركز ذيصلاح به مدارس مراجعه و در جلسهاى كه با هماهنكى مدير مدرسه ترتيب داده شد اهداف تحقيق براى والدين شرح و از آنها دعوت به همكارى شد. والدين داوطلبان

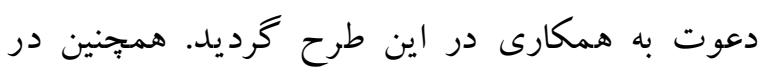
مدرسه نيز شماره تماس تمام نمونههاى واجد شرايط و داوطلب شركت در تحقيق از طريق مديريت مدرسه دريافت و با تمام آنها تماس گرفته شد و اهداف تحقيق كاملاً توضيح داده شد و والدين داوطلب براى ادامه كار انتخاب و دعوت شدند. گرديد. طى يكك ملاقات با والدين داوطلب، فرم رضايتنامه در اختيارشان قرار داده شد. بعد از دريافت رضايتنامه بر اساس متغيرهاى بيشبينى شده در اين تحقيق فراهمسازها بر اساس امكانات يا آموزش و تمرين در محيط مدرسه براى دانش آموزان تهيه مىشود ارائه شد. 
روانيزشكى ابداع كرد. اين آزمون متشكل از دو كارت و A موقعيت انتخاب شده و اجرا مى گردد. كارت A متشكل از ^| جزء ادراكى است و در مورد افراد f سال به بالا كاربرد دارد. كارايى مؤثر اين كارت براى افراد، از ل سال به بعد است و براى نوجو انان و بزرگكسالان عملاً

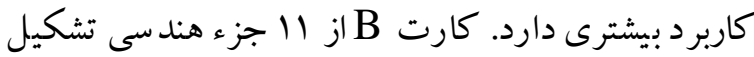
شده، مكمل كارت A است و براى كودكان زير 1 سال ساخته شده است. هم جِنين از اين آزمون براى عقبماند گى هاى ذهنى استفاده مىشود. هنجاريابى اين آزمون در ايران توسط يناهى (rیr|) انجام شده است، وى ضريب روايى ملاكى بر ابر ه/ • و ضريب اعتبار /4Y •

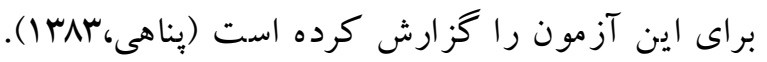
نتايج تحليل همسانى درونى در اين تحقيق نشان داد كه ضريب آلفا براى مقياس كلى 194 • است. فراهم سازها! براى بررسى تأثير فراهمسازها در محيط

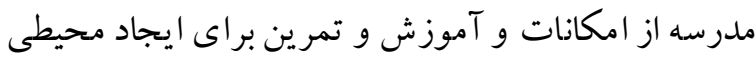
با قابليت زياد در راستاى متغيرهاى مورد تحقيق استفاده

فضاى فيزيكى يكى از موارد بسيار مهم در محيط است

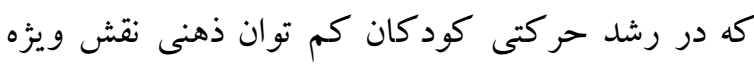
اى دارد (Y)). در اين تحقيق محيط آموزشى تحقيق داراى امكانات سخت افزارى و وسايل بازى شامل تاب،

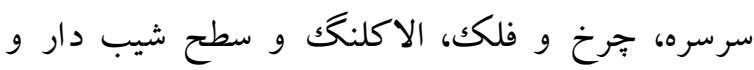
استخر توب است بود. همجِنين لازم به تأكيد است كه آموزشهاى مرتبط با فعاليتهاى ورزشى توسط مربيان كار آزموده و كادر درمانگران داراى تجربه آموزش كود كان داراى اختلالات ذهنى انجام مى گرديد. همجنين
براى هر خرده آزمون بهدست آمده است پايايى اين آزمون از طريق آلفاى كرونباخ و روايى آن از طريق همبستكى نمره خرده مقياسها با نمره كل آزمون به

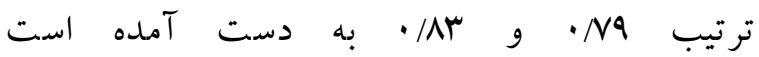
(حميديان، צrاן). نتايج تحليل همسانى درونى در اين تحقيق نشان داد كه ضريب آلفا براى مقياس كلى AF/ • و

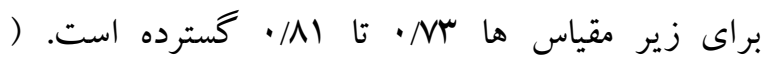
كامكارى، • •

آزمون توجه تولوز- بيرون: آزمون تولوز-ييرون جزو معتبر ترين مقياسهاى سنجش تو جه است كه در مطالعات

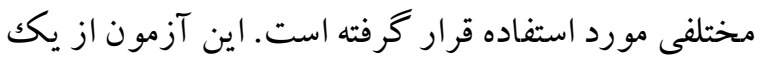
مربعات دنباله دار تشكيل شده است كه در بالاى صفحه سه مربع دنباله دار با جهت هاى مختلف به عنوان نمونه تعيين شده و آزمودنى مىبايست تمام مربعات با دنباله مشابه مربعات بالا را در زمان تعيين شده (r دقيقه) مشخص كند. اين آزمون در موقعيتهاى عادى و تكليف اضافى (شمارش ذهنى اعداد) انجام مى گيرد. شيوه نمره كذارى نيز به اين صورت است كه به ازاى هر مربع درست علامت خورده يكك نمرهُ مثبت و براى هريك از مربعات غلط علامت خورده و فراموش شده نيم نمره منفى در نظر كرفته مىشود. جمع جبرى نمرات مثبت و

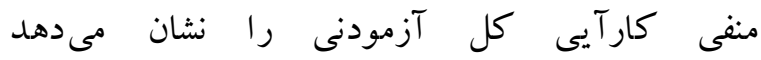
(كنجى، (گarا). نتايج تحليل همسانى درونى در اين تحقيق نشان داد كه ضريب آلفا براى مقياس كلى AF/ . آزمون حافظه آندره روى: آزمون (تصاوير هندسى درهم")

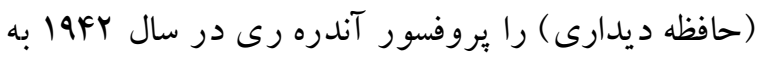
منظور سنجش نوع فعاليت ادراكى حافظه ديدارى

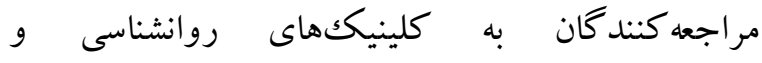


استنباطى، ابتدا به كنترل مفروضات آزمونهاى بارامتريك برداخته شد. به اين صورت كه با بآزمون كلمو گروف اسميرنف وضعيت بهنجار (نرمال بودن) دادههاى خام و با آزمون لون، مفروضات همخنى واريانس ها كنترل شد. براى بررسى و تحليل آمارى دادهاى خام از آمار توصيفى و استنباطى استفاده شد. اطلاعات به دست آمده با كمكك SPSS19 مورد تجزيه و تحليل قرارگرفت و از تحليل كوواريانس استفاده شد.

يافته ها جدول ا ميانگين و انحراف معيار ويز گكى هاى فردى دو كروه آزمايشى و كنترل را نشان مى جدهد.
بازى هاى ادراكى -حركتى براى تقويت توجه و حافظه طراحى شده در مداخله حاضر بر اساس كتاب اختلالهاى عاطفى و رفتارى (يارمحمديان، IMMM) و مهارتهاى مورد نياز كود كان براى ورود به مدرسه (عابدى، .هrاן)

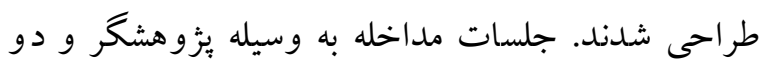
نفر دستيار روان شناس كارشناسى ارشد انجام شد و بعد از يايان جلسات يس آزمون روى هر دو گرُوه از كود كان اجرا شد. به منظور رعايت اخلاق بُزوهش، فرآيند و اهداف تحقيق براى مسئولين مدرسه و مربيان و والدين دانش آموزان توضيح داده شد و آنها توجيه شدند كه اين مطالعه تنها يك تحقيق بثزوهشى است و كسانى كه تمايل ندارند مى توانند شركت نكنند. در بخش آمار

\begin{tabular}{|c|c|c|}
\hline كرو آزمودنى هاه كنترل & بن و انحرواف معيار و. & متغير \\
\hline ميانخين و انحر اف معيار & ميانكين و انحراف معيار & \multirow[t]{2}{*}{ سن } \\
\hline$V / Q \pm \cdot / \Lambda$ & $V / F \pm . / 9$ & \\
\hline $1 \cdot 1 / N \pm V / 9$ & $1 \cdot \Lambda / r \pm V / r$ & قد \\
\hline$r \Delta N \pm 1 / \Lambda$ & $r F / r \pm 1 / 9$ & وزن وز \\
\hline $\mid F / r \pm r / A$ & $\mid \theta / F \pm r / 1$ & درصد جربى \\
\hline
\end{tabular}

جدول ץ نتايج آزمون هاى مقدماتى تحليل كواريانس براى خرده مقياس حافظه

\begin{tabular}{|c|c|c|c|c|c|c|c|c|}
\hline \multicolumn{2}{|c|}{ همعنى شيب } & \multicolumn{2}{|c|}{ وآزمون بر ابرى } & \multicolumn{2}{|c|}{ آزمون نرماليتى } & \multirow{2}{*}{ مرحله } & \multirow[t]{2}{*}{ كروه } & \multirow[t]{2}{*}{ متغير } \\
\hline \multirow[t]{2}{*}{ معنى دارى } & آماره & معنى دارى & آماره & معنى دارى & آماره & & & \\
\hline & & & &.$/ \cdot \wedge r$ & $.19 \mathrm{VF}$ & بيش آزمون & \multirow{2}{*}{ تجربى } & \multirow{4}{*}{ 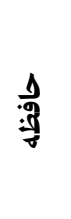 } \\
\hline \multirow{3}{*}{.$/ 4 r \Delta$} & \multirow{3}{*}{ I/TaF } & \multirow{3}{*}{ - / MAF } & \multirow{3}{*}{$Y / \Delta F$} & $\cdot / T \Delta F$ & $\cdot / V F A$ & يس آزمون & & \\
\hline & & & &.$/ 114$ &.$/ 99 \mathrm{~V}$ & بيش آزمون & \multirow{2}{*}{ كنترل } & \\
\hline & & & & $\cdot /$ TAF & $\cdot / 9 R \mathrm{~V}$ & پِ آزمون & & \\
\hline
\end{tabular}

طبيعى بيروى مى كند؛ زيرا در تمامى اين مراحل مقدار نتايج آزمون نرماليتى نشان مى دهد كه در مراحل آزمايش معنى و در بين گروههاى شركت كننده، نمرات حافظه از توزيع 
است. نتايج آزمون لون نيز بيان مىدارد كه مقدار ركرسيون كه از بيشفرضهاى مورد نياز تحليل

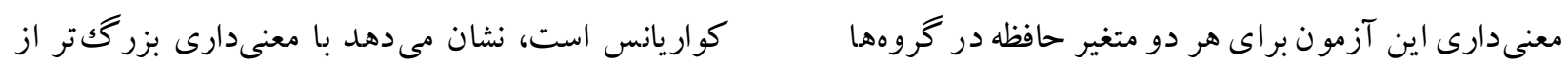

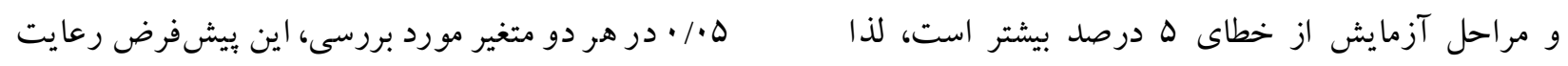

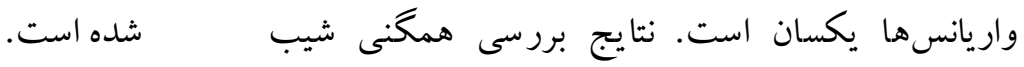

جدول ب نتايج تحليل كواريانس تكك متغيره براى بر رسى تأثير فراهم سازى بر خرده مقياس حافظه

\begin{tabular}{|c|c|c|c|c|c|c|c|c|}
\hline توان & مجذور & سطادارى & $\mathbf{F}$ & مجانكين & آزادى درجه & مجذورات مجموع & تغييرات & متغير \\
\hline $1 / \cdots$ & $.194 \mathrm{~A}$ & $\cdot / \cdots$ & $P V / \Delta \wedge q$ & $\mid r 4 / .94$ & 1 & $1 \mathrm{ra/.94}$ & يِش آزمون & \multirow{4}{*}{ حافظه } \\
\hline \multirow[t]{3}{*}{$\cdot / \cdot \Delta$} & $\cdot / \cdots$ & $\cdot / 971$ &.$/ \cdot 1$ &.$/ \cdot F$ & 1 &.$/ \cdot f$ & كروه & \\
\hline & & & & $r / 90$. & FF & $V I / \Delta F$. & خطا & \\
\hline & & & & & FV & T. FA & كل & \\
\hline
\end{tabular}

(9VI/9)، معنادار نبودن آن تائيد شده است؛ به عبارت ديخر، تفاوت ميان ميانگين حافظه، بس از كنترل متغير ييش آزمون در دو گروه آموزش و كواه معنادار نيست. توان آمارى ها درصدى نيز حاكى از دقت آمارى يايين و و و عدم كفايت حجم نمونهى اين بثوهش است؛ بنابراين مىتوان نتيجه گرفت كه برنامهى فراهم سازى نتو انسته است تأثير معنادارى در حافظه داشته باشد.
نتايج آزمون تحليل كوواريانس را بر روى ميانگين

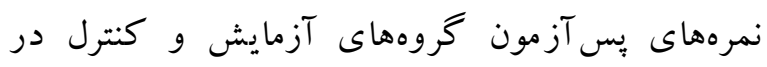
نمرهى (حافظه) نشان مىدهد. نتايج اين آزمون نشان مىدهد كه نمرهى بيش آزمون اثر معنادارى در سطح 99 درصد بر نمرهى بس آزمون داشته است؛ اما مقادير به دست آمده براى تأثير گروه نشان مىدهد كه هيج درصدى از تغييرات نمرات يس آزمون ناشى از عامليت كروهى نبوده كه با توجه به سطح معنادارى به دست آمده

جدول . Error! No text of specified style in document نتايج آزمون هاى مقدماتى تحليل كواريانس براى خرده مقياس توجه آزه

\begin{tabular}{|c|c|c|c|c|c|c|c|c|}
\hline \multicolumn{2}{|c|}{ همكنى شيب } & \multicolumn{2}{|c|}{$\begin{array}{c}\text { آزمون بر ابرى } \\
\text { واريانس خطا } \\
\text { (لون) }\end{array}$} & \multicolumn{2}{|c|}{ 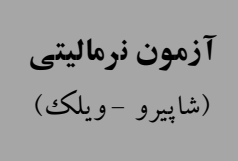 } & \multirow[t]{2}{*}{ مرحله } & \multirow[t]{2}{*}{ كروه } & \multirow[t]{2}{*}{ متغير } \\
\hline معنى دارى & Tاره & معنى دارى & Tآماره & معنى دارى & Tاره & & & \\
\hline \multirow{4}{*}{ - Mar } & \multirow{4}{*}{$\cdot /$ N } & \multirow{4}{*}{ - /YAF } & \multirow{4}{*}{$\cdot / 490$} & / $/ \Delta Y V$ & ./AVF & بيش آزمون & \multirow{3}{*}{ تجربى } & \multirow{4}{*}{$\begin{array}{l}12 \\
4 \\
4\end{array}$} \\
\hline & & & & . / $\wedge \Delta$ & / / AST & پِ آزمون & & \\
\hline & & & & . / rak &.$/ Q Y V$ & ييش آزمون & & \\
\hline & & & & .1199 &.$/ Q \Delta F$ & پֶ آزمون & كنترل & \\
\hline
\end{tabular}

براساس يافتهاى جدول، با توجه به اين كه نتايج نشان مىدهد دادههاى متغيرها از فرضيهى همخنى شيبهاى 
تحليل كوواريانس استفاده شده است. اين نتيجه حاكى از طبيعى بودن توزيع دادههاى متغيرهاى مذ كور در مراحل آزمايش و در بين گرووهاى آزمودنى است.
ركرسيونى تبعيت نموده و همجنين نتايج آزمون لون براى بررسى همخنى واريانسها نشان مىدهد كه دادههاى

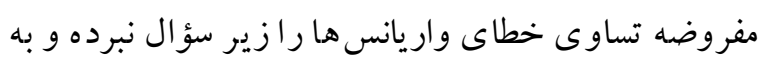

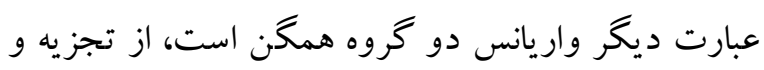

جدول ه نتايج تحليل كواريانس تكك متغيره براى بروسى تأثير فراهمسازى بر خرده مقياس توجه

\begin{tabular}{|c|c|c|c|c|c|c|c|c|}
\hline توان & مجذور اتا & معنادارى سطح & $\mathbf{F}$ & مجذوروات مينين & درجه & مجذوروات & تغنييرات & متغير \\
\hline $1 / \cdots$ & $\cdot / N=1$ & $\cdot / \cdots$ & $W / Y \Lambda$. & $r \Delta 1 . / V$. & 1 & $r \Delta I . / / V$. & ييش آزمون & \multirow{4}{*}{ توجه } \\
\hline \multirow[t]{3}{*}{$1 / \ldots$} & .194. & $\cdot / \ldots$ & $\mu \varphi / \cdot \wedge r$ & |FFl/Aq. & 1 & IFTI/Aq. & كروه & \\
\hline & & & & rY/FAl & Fq & $\wedge \mathrm{V} /$ /9४ & خطا & \\
\hline & & & & & FV & $9 . \pi / 1 / 0 .$. & كل & \\
\hline
\end{tabular}

و باعث افزايش معنادار توجه آزمودنىهاى گرووه

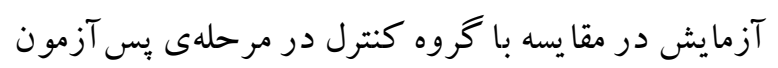

شده است.

بحث

محيط ساخته شده مجموعه اى از انطباق بذيرى هاست

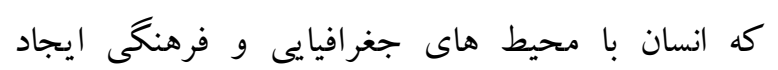
مى كند. ساماندهى محيط، رو ابط متقابل مردم و محيط

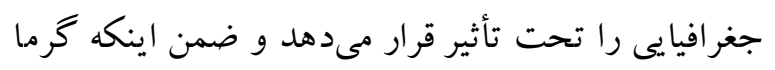
و نور، صوت و بو و تماسهاى مكانيكى فرد را تغيير مىدهد؛ تا حدودى نيز از تغييرات محيط اجتماعى و فرهنگى مردم تأثير مى گيرد. مردم براى باسخ به تمايلات خود به محيط رجوع مى كنند. بعضى محيطها ممكن

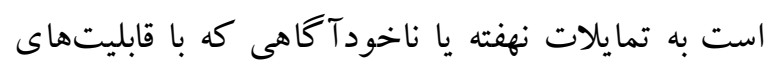
الكوى ويزهاى از محيط بروز مى كنند باسخ كويند.

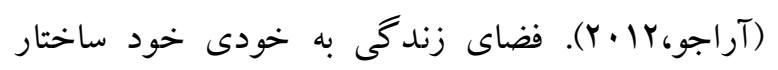
ديناميكى ندارد، بلكه بررسى هاى انخيزشى مورد نياز

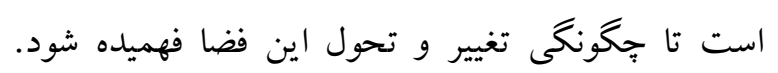

نتايج آزمون تحليل كوواريانس را بر روى ميانگين

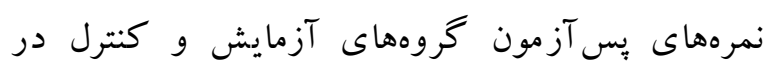
نمرهى (اتوجه) نشان مىدهد. نتايج اين آزمون نشان

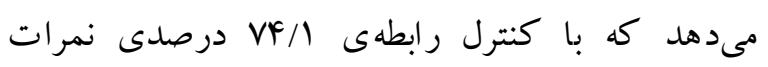

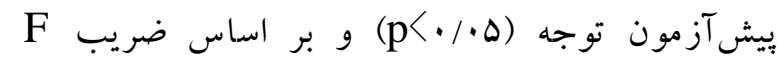
محاسبه شده، تفاوت معنادارى بين ميانگين بر آورد شدهى لئ

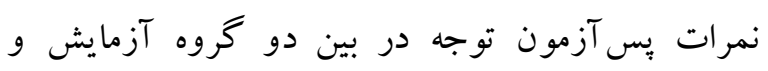
كنترل وجود دارد؛ به عبارت ديخر، تفاوت ميان ميانگين يس آزمون توجه، بِ إز از كنترل متغير بيش آزمون در دو كروه آزمايش و كنترل معنادار است. ميزان تفاوتها لونها حاكى از آن است كه دريافت بو درصد كوواريانس نمرات يّ آزمون، ناشى از برنامهى فراهم سازى بوده است؛ يعنى بو درصد تفاوت موجود در ميانگين نمرات توجه دو گروه در مرحلهى بِ آزمون ناشى از عامل

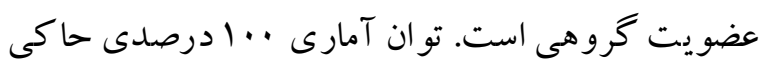

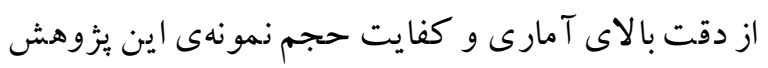
است؛ بنابراين با اطمينان بيش از لهو درصد اطمينان

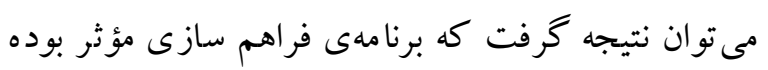


توجه كودكان كمك خواهد شد. تحقيقات نشان داده است كه فعاليت بدنى و محيطهاى آموزشى مناسب براى تحر كك مى تواند در تنظيم انتقال دهنده هاى عصبى هسته هاى قاعدهاى مغز كه كنترل سيستم تغيير توجه از يكك

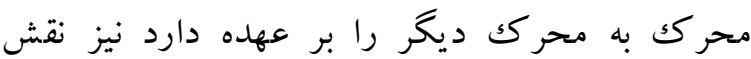
تعيين كنندهاى داشته باشد. باكك و همكارانش (Y.V. بيان مى كنند كه سطح بالايى از آمادكى جسمانى كود كان كه متعاقب تمرينات حركتى حاصل مىشود، با يارامترهاى تو جه، حافظهى كارى و سرعت پياسخ دهى در ارتباط هستند. اين يافته ها نيز تحقيق حاضر را تائيد مى كنند. نتايج حاصل از ئوهش حاضر با تحقيق

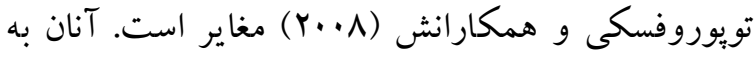
اين نتيجه رسيدند كه شركت كودكان در تمرينات هوازى موجب بهبود برخى از عملكردهاى اجرايى از جمله برنامه ريزى مى شود؛ اما در ساير متغيرهاى شناختى مثل توجه، عملكرد بيوسته و يا همزمان، مهارتهاى ادراكى و هماهنكى بينايى حركتى تأثيرى ندارد. اين مغايرت ممكن است ناشى از تفاوت برنامه هاى تمرينى به كار رفته د راين دو تحقيق باشد. با توجه به نتايج اين تحقيق و نتايج تحقيقات كذشته مى توان بيان داشت كه فراهم سازى محيط و استفاده از قابليت محيط مى تو اند سبب بهبود توجه در كودكان داراى اختلالات ذهنى

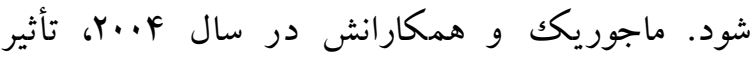
حركات موزون كه نوعى از حركت درمانى است را بر

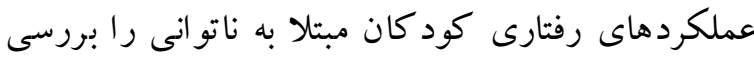
كردند و اثرات مثبت برنامهاى حركتى را بر دامنهى توجه، تمركز، ريتم كار و مهارتهايى ماند هماهنكى جالاكى و رفتار اجتماعى گز ارش د ادند. يكى ديخر از مكانيسمهاى احتمالى كه منجر به بيشرفت
هدف از تحقيق حاضر بررسى تأثير قابليت محيط (فراهم سازها) در توجه و حافظه كود كان داراى اختلال ذهنى 9 تا 9 ساله بود. نتايج تحقيق حاضر نشان داد كه فراهم

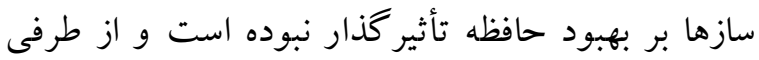
تو انسته است مهارت توجه را در كود كان داراى اختلال ذهنى بهبود دهد.

يكى از ويز گیى هاى برجسته دانش آموزان داراى اختلال ذهنى سطح تمر كز ضعيفشان در موقعيت يادگيرى رسمى است. آنها به ويزه در توجه انتخابى، حفظ توجه، تقسيم توجه بين ابعاد مختلف تكليف و توالى بردازش اطلاعات بيشترين مشكل را دارند. تو جه ضعيف، توانايى دريافت اطلاعات و يادگيرى از طريق مشاهده و تقليد را به طور قابل ملاحظه اى كاهش مىدهد. تا حدودى به خاطر توجه ضعيف (البته در مواردى نيز به دلايلى ديخر) دانش آموزان كم توان ذهنى، بردازش اطلاعات و بِاسخ دهى شان زمان زيادى طول مى كشد. نتايج با تحقيقات

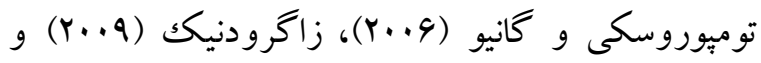

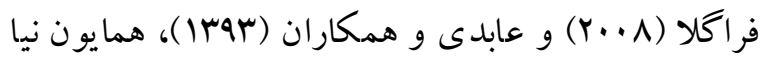
و همكاران (IrQV ) همسويى و با تحقيق تومِيوروسكى ناهمسو بود. اين محققان در تحقيقاتى به بررسى (Y.人)

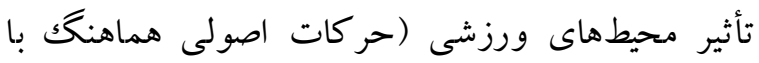
موزيك) بر كار كردهاى اجرايى توجه كودكان به ويزه كود كان با ناتو انى ها يرداخته بودند. در تبيين اين موضوع مىتوان اشاره نمود بهبود كار كردهاى اجرايى و توجه تا حدود زيادى به تجارب كودكك ارتباط دارد. كودكك تجارب خود را از طر يق گوناگُ ن به ويثزه بازى ها در طى دوران رشد به دست مى آورد. بنابراين، اگر بتوان به غنى

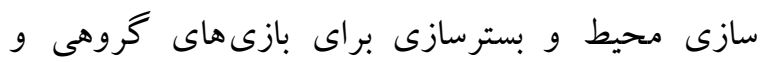

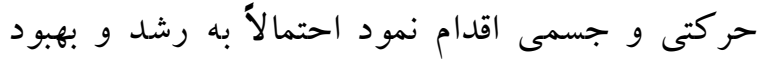


در مرحله ياددارى بر حافظه كو تاه مدت و كارى تأثيرى

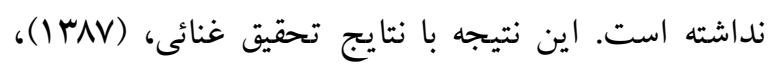

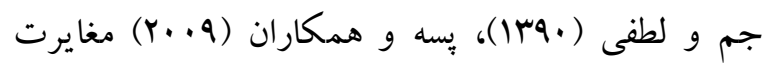
دارد. دلايل اين مغايرت را مى توان در متفاوت بودن نوع

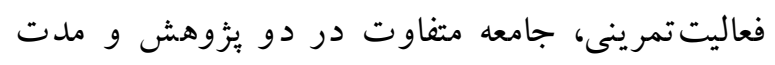
زمان تمرينى كه در تحقيق وى نسبت به بزوهش حاضر بسيار بيشتر بوده است بيان كنيم. همينطور نتايج اين

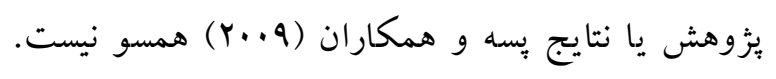
كه اين ناهم سويى را مى توان به دليل جامعه متفاوت مورد مطالعه يُه و همكاران، دانست. آنها از افراد بهنجار استفاده كرده بودند. همجِنين تمرينات متفاوت مى تو اند ديخر علل ناهم سو يى نتايج باشد، زيرا كه بِه و همكاران از تمر ينات هو ازى و بازىهاى تيمى استفاده كرده بود دند

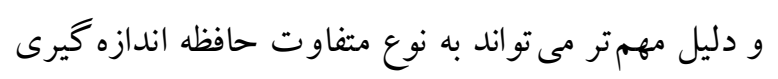
شده مربوط باشد. در تحقيق بِه و همكاران، حافظه آز اد،

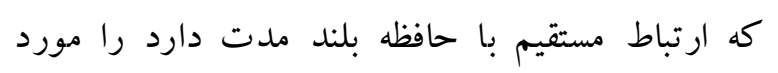

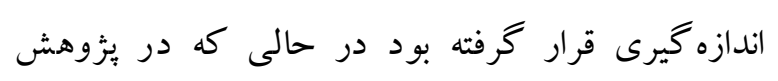
حاضر، حافظه كارى و كو تاهمدت كه همبستخى بيشترى با مفاهيم شناختى و فرايندهاى تصميم گيرى دارند، مورد

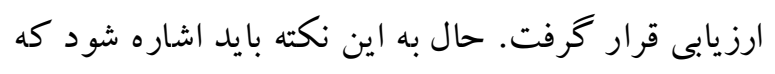
نتايج يس آزمون، عليرغم عدم معنىد ارى، بهبود عملكرد د را نسبت به نتايج بيش آزمون نشان مىدهد. در مطالعات بـات

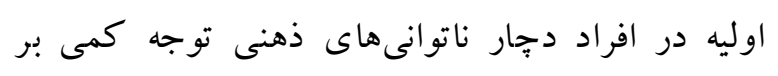
درمان قرار داده شده بود. نتايج اين يزوهش با نتايج

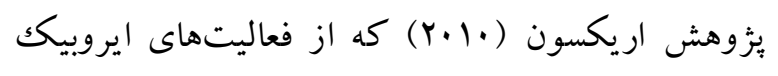
براى كاهش زوال حافظه در بزركُسالان استفاده كرده است مغايرت دارد. اريكسون در يزوهش خود به اين نتيجه رسيد كه انجام تمرينات بدنى مىتواند حجم هييو كمٍ را افزايش دهد به اين دليل كه با انجام
عملكردهاى شناختى در اثر تمرينات بدنى مىشود را مى توان افزايش جريان خون مغزى دانست. مطالعات بر روى حيوانات نشان داد كه شركت در فعاليتهاى بدنى باعث افزايش جريان خون مغزى در نواحى كنترل حركتى، تعادل و قلبى ريوى و همجِنين مناطقى از

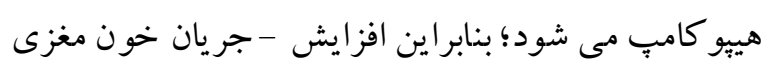
ناشى از تمرينات حركتى، ممكن است سوخت بيشترى را جهت عملكردهاى عصبى تأمين كرده و مواد زائد متابوليكى موجود در اين نواحى را از بين ببرد و از اين طريق باعث بهبود عملكردهاى شناختى از جمله توجه شود. همجينين به كفتهى ديشمن و همكارانش (9. (Y)، فعاليت هاى بدنى مى تو اند شكل بذيرى مغز را بهواسطهى

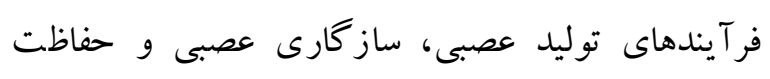
عصبى به طور مثبتى تغيير دهد. مى توان بيان داشت كه

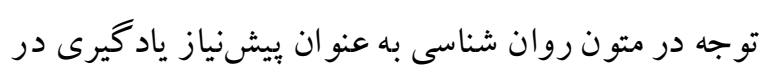

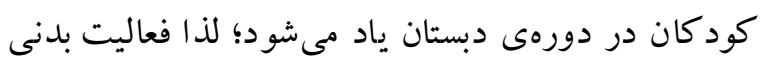

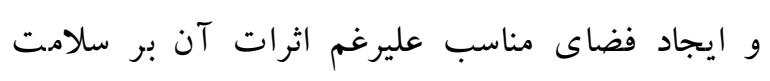
جسمانى و شادى كود كان در جهت رشد و بهبود توجه مى شود؛ زيرا تمام كاركردهاى جسمانى و شناختى مانند توجه در گير مىشوند. نتايج يثزوهش نشان داد كه فر اهم سازى بر حافظه كود كان داراى اختلال ذهنى 9 تا 9 تأثير معنىدارى ندارد. نتايج

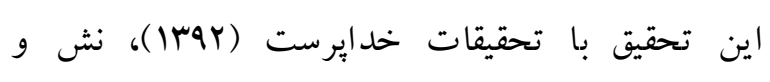

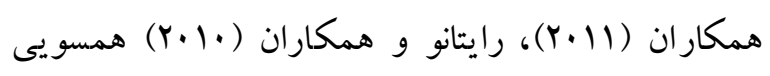

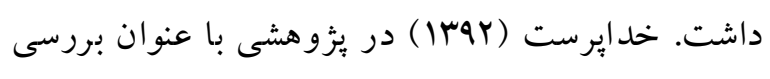
تأثير يكك دوره تمرين بدنى و مرور ذهنى بر حافظهى كارى و حافظهى كوتاهمدت كودكان V تا بان سال سندروم داون بيان داشت كه تأثير شيوهاى مختلف تمرين بدنى و مرور ذهنى بر حافظه كو تاه مدت و كارى 
مىدانيم مطالعات نوروفيزيولوزيكى نشان دادهاند كه هييو كامٍ نقش كليدى در جنبهاى مشخصى از يادگيرى و حافظه دارد. با وجود اينكه مكانيسم دقيق عملكردهاى حافظه از طريق مسيرهاى هييو كمبى هنوز روشن نيست ولى به نظر مىرسد كه اين منطقه براى سيستم حافظه بيانى در انسانها ضرورى باشد. همانطور

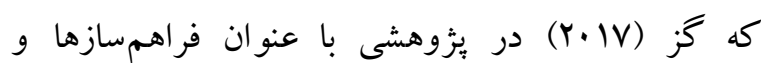
محدوديت ها در رشد حر كتى و يادگيرى كود كان داراى اختلال هماهنگ رشى رشدى نشان دادند كه نقش محدوديت وديت ها به عنو ان يكى كليد اساسى در رشد حركتى و يادگيرى باعث دركك درستى از مفهو ر رشد دارد. بايد بيان داشت كه يكى از علت هايى كه در اين تحقيق حافظه نتو انست با استفاده از فراهم سازهاى محيطى بهبود يابد مدت كم شر ايط محيطى مناسب براى بهبود حافظه در اين كود كان بود. اين تحقيق نشان داد كه دركك فراهم سازها و درك تغييرات رشدى در كودكان داراى اختلالات ذهنى بسيار مهم است تا با استفاده از اين درك بتو ان نسخه مفيد براى بهبود حافظه كود كان داراى اختلال ذهنى صادر كرد. نقاط قوت اين تحقيق مى توان به ايده نو همراه با تحقيقات و يزٔوهشهاى ميدانى و كتابخانهاى لازم جهت انجام اين يثزوهش و همراهى كامل والدين و مسئولين مدارس شهرستان با اين كار تحقيقاتى را بيان داشت همجنين اين يزوهش با محدوديتهايى مانند عدم استفاده از آزمون

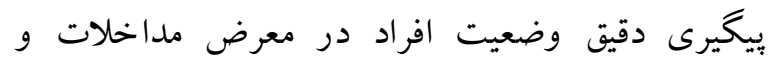
همجنين محدوديت سنى افراد و تعداد كم آزمودنىها همر اه بود. همجِنين استفاده از تنها يكك جنس (يسر) نيز از محدوديت هاى اين بثوهش بود. بيشنهاد مىشود تقويت فراهمسازها در جهت بهبود توجه در برنامك توانبخشى و آموزشى كودكان مبتلا
تمرينات ورزشى خونرسانى به هييو كامبٍ افزايش مى يابد، علاوه بر آن با انجام فعاليتهاى ورزشى سطح سرم BDNF كه يك ميانجى نوروزنز در شكنج دند انهاى است، افزايش مى يابد. آنها در ئزوهش خود از تمرينات ايروبيكك استفاده كردهاند. تمرينات هو ازى در اين يزوهش سبب افزايش حجم هيبو كامبٍ شده و سطح سرم BDNF را افزايش داده است. نوع متفاوت تمرينى مى تواند دليلى براى مغايرت دو يُزوهش باشد، از طرفى

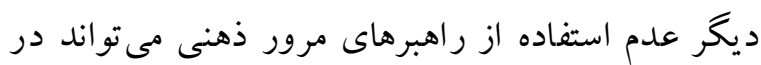
اين افراد موجب كاهش عملكرد آنها باشد. زيرا براى

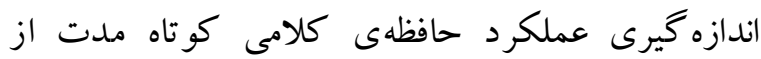
فراخناى ارقام رو به جلو استفاده شد، حال اينكه شايد تمرينات بدنى موجب افزايش عملكرد ذهنى اين افراد شده باشد اما مطمئناً در بهبود فرايندهاى مربوط به بـ باسخ، از جمله مرور ذهنى كمكى نكرده است.

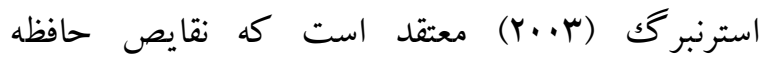
كودكان داراى اختلالات ذهنى ناشى از عدم رشد فرايندهاى فراشناختى مهمى است كه به بيوند بين اطلاعات جديد با اطلاعات قبلاً آموخته شده آنها كمكك مى كند. بسيارى از دانش آموزان كمتوان ذهنى در ذخيرهسازى اطلاعات در حافظه بلندمدت مشكلات زيادى دارند. صرفنظر از علت اصلى مشكل، تأثير محدوديت در حافظه اين است كه ذخيرهسازى اطلاعات زمان زيادى طول مى كشد و نيازمند تكرار بسيار زياد است. هويكينس و همكاران (Y (Y.Y)، رو گك و همكاران

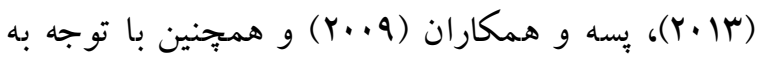
اينكه فعاليتبدنى سبب افزايش خونرسانى به هييو كامٍٍ شده و اين افزايش خونرسانى سبب افزايش حجم

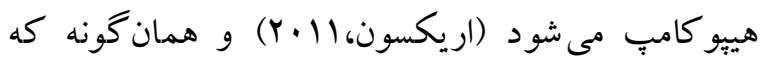


Bell, Paul A., Greene, Thomas C., Fisher, Jeffery D., Baum, Andrew. (2005). Environmental Psychology. (FifthEd.). EarlMcPeek.

Bjørgen K. (2015). Physical activity in light of affordances in outdoor environments: qualitative observation studies of 3-5 years olds in kindergarten, springerplus, 5(1):950.

Burgeson CR, Wechsler H, Brener, ND, Young J C, Spain CG. (2001). Physical education and activity; results from the schoolhealth policies and programs study. International Joumal of School Health 71(7):279-293.

Chen, F. C. Tsai, C. L. Wu,S. K. (2014). Postural sway and perception of affordances in children at risk for developmental coordination disorder, Experimental Brain Research, 23221552165.

Danks, S. G. Asphalt to ecosystems: Design ideas for schoolyard transformation. Oakland, CA 2010: New Village Press.

Devaud, J.M., Acebes, A., Femus, A. (2001). Odor exposure causes central adaptation and morphological changes in selected olfactory glomenuli in Drosophila. The Journal of Neuroscience;(15):6274-6282.

Ferguson GD, Jelsma D, Jelsma J. (2015). The efficacy of two task-orientated interventions for children with Developmental Coordination Disorder. Neuromotor task training and nintendo wii fit training. Research in DevelopmentalDisabilities;(34)2449-2461.

Gabbard C, Caçola, P, Spesatto, B., \& Santos, D. (2015). The home environment and infant and young children's motor development. In A. M. Columbus (Ed.), Advances in Psychology Research, 90(5). 105-123.

Gallahue, D. L., \& Ozmun, J. C. (2008). Understanding motor development: Infants, children, adolescents, adults, (6th ed.).

Geuze R H. (2017). On constraints and affordances in motor development and leaming - The case of DCD. A commentary on Wade \& Kazeck, Human Movement Science. 3(4), 47-61.

Gharaei F, Arabameri E, Huminiyan D.(2014).The Effect of (Perceptual-Motor and Music) Enrichment of Environment on Age

$$
\begin{aligned}
& \text { موردتوجه قرار گيرد، جرا كه بهبود عملكرد تو جه به } \\
& \text { افزايش توانايى يادگيرى در اين كودكان منجر خواهد } \\
& \text { شد. در شروع هر سال تحصيلى طرح سنجش تو انايى } \\
& \text { رشد و شناسايى كودكان كم توان ذهنى داراى اختلال } \\
& \text { ذهنى نيز بركزار شود تا اين كود كان شناسايى و در همان } \\
& \text { مراحل ابتدايى درمان گردند، از طرفى براى استفاده از } \\
& \text { فراهم سازها در جهت بهبود حافظه بايد كمى محتاطانه }
\end{aligned}
$$

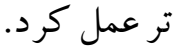

$$
\begin{aligned}
& \text { نتيجه كيرى } \\
& \text { يافتهاى بزوهش نشان داد كه لازم است به محيط و } \\
& \text { توانيىهاى محيطى و استفاده از روشهاى مناسب } \\
& \text { فراهمسازى در جهت افزايش توجه در كودكان داراى } \\
& \text { اختلال ذهنى توجه ويزه داشت و با استفاده از قابليت } \\
& \text { محيط مهارتهاى توجه را در كود كان داراى اختلال } \\
& \text { ذهنى بهبود بخشيد از طرفى در مورد حافظه نيازمند } \\
& \text { تحقيقات بالينى سازمان يافته تر است تا بتوان بهطور يقين } \\
& \text { در مورد تأثير فراهمسازها در حافظه نظر داد. }
\end{aligned}
$$

\section{Refrences}

Audrei F. Miquelotea, Denise C.C. Santosa, Priscila M. Cac, olab, Maria Imaculada de L. Montebeloa, Carl Gabbardc. (2012). Effect of the home environment on motor and cognitive behavior of infants, Infant Behavior and Development, 35,329-334.

Baker JK1, Fenning RM, Crnic KA, Baker BL, Blacher J. A (2007). descriptive study of the difficulties delayed students encounter white mastering and transferring social skills,205,959-70.

Equivalents of Gross and Fine Motor Movements in 5-8-Month-Old Infants, 
Jourmal of Develoment and Motor Leaming, 6(1):75-89(Persian)

Hamarstrom, J. C. (2012). Perceptions of naturalized playgrounds: A qualitative study (Master's Thesis). Utah State University, Logan.

Hamidian Iahromi N, Rezaeeyan F, Haghighat S. (2012). The Effect of Native and Local Games on the Students' VisualMotional Growth among mentalretarded students inPre-School and Elementary First-Graders in the city of Shiraz Exceptional Education; 3 (111):2938(Persian)

Homaynnia Firoozjah M, Sheikh M, Hemayat tlab R, Shahnaz S.)2018)The Effect of Provision (Educational Environment and Physical Activity) on the Improvement of Motor Moments in Children with Mental Disorders. Armaghane danesh. 23 (3):334-349(Persian)

Kamkari, K.( 2012).The comparison of diagnostic validity of new version of tehran- stanford binet intelligence scales (TSB-5) and wechsler intelligence scales for children- fourth edition (WISC-4) in children with leaming disability, Quarterly Journal of Leaming Disabilities; 4(2),70-83(Persian)

Kuh, L. P., Ponte, I., \& Chau, C. (2013). The impact of a natural playscape installation on young children's playbehaviors. Children, Youth and Environments, 23(2), 49-77.

Kuh, L. P., Ponte, I., \& Chau, C. (2013). The impact of a natural playscape installation on young children's playbehaviors. Children, Youth and Environments, 23(2), 49-77.

Kytta, M. (2004). The extent of children's independent mobility and the number of actualized affordances as criteria for child-friendly environments. Journal of Environmental Psychology, 24, 179e198.
Lewis CL, Fragala-Pinkham MA. (2005). Effects of aerobic conditioning and strength training on a child with down syndrome: a case study. Pediatr Phys Ther. Spring., 17(1):30-6.

Müllera, a, B. Valentinic N, C. Bandeiraa P, and F. (2017). Affordances in the home environment for motor development: Validity and reliability for the use in daycare setting, Infant Behavior and Development, 47,138-145.

Müllera,A, B. Valentinic N, C. Bandeiraa P, F. (2017). Affordances in the home environment for motor development: Validity and reliability for the use in daycare setting, Infant Behavior and Development, 47,138-145.

Nagamatsu LS, Chan A, Davis JC, et al. (2013). Physical activity improves verbal and spatial memory in older adults with probable mild cogni tive impairment: a 6-months randomized controlled trial J Aging Res; 33:861-893.

Simons J, Daly D, Theodorou F, Caron C, Simons J, Andoniadou E. (2008). Validity and reliability of the TGM-2 in 7-10 year-old Flemish children with intellectual disability. Adapted Physical Activity Quarterly.; 25(1):71-82.

Smith MM, Anderson HI. (2000). Coping with clumsiness in the school playground:Social\& physical play in children with coordination impairments. British Journal of DevelopmentalPsychology.; 18(3):389-413.

Yildirim N, ErbahceciF, Ergun N, Kenneth HP, Beets M. (2010). The effect of physical fitness training on reaction time in youth with intellectual disabilities. Percept Mot Skills.; 111:178-186.

Ziereis S, Jansen P. (2015). Effects of physical activity on executive function and motor performance in children with ADHD. Research in DevelopmentalDisabilities; 38: 181-191. 